\title{
RECENT ALTERATIONS OF AEROSOL CONCENTRATION, MERCURY DISTRIBUTION AND ORGANIC MATTER DEPOSITION IN THE ARCTIC
}

\author{
JANUSZ PEMPKOWIAK, TYMON ZIELIŃSKI, TOMASZ PETELSKI, \\ AGATA ZABORSKA JACEK BEŁDOWSKI \\ Institute of Oceanology PAS \\ Powstańców Warszawy 55, 81-712 Sopot, Poland \\ e-mail:pempa@iopan.gda.pl
}

\begin{abstract}
Material fluxes in the Arctic and Antarctic have been, in several respects, strongly affected recently. For example, atmospheric turbidity conditions are frequently subject to strong changes due to haze and dust transport episodes, which can cause considerable perturbations in the radiation balance of the atmosphere beyond regional scale. This, directly or indirectly, contributes to the increased mercury deposition and organic matter fluxes to sediments.

The results show that local emissions are not always the most important factors influencing the composition of aerosol in the atmosphere of the west Spitsbergen region. The direct radiative impact of polar aerosols on the surface and at the top of the atmosphere (TOA) need to be studied more closely through both theoretical studies on the aerosol radiative properties and measurements of the surface reflectance characteristics.

Mercury dissolved/solid partitioning, both in the unconsolidated, fluffy layer of suspended matter covering the sediments, and the uppermost sediment layer, indicate that the influence of the athmospheric mercury deposition event (AMDE) can prolong well into summer (July/August), and can provide a pathway to the food chain for mercury contained in sediments.

Since terrigenous supplies of organic carbon to the Barents Sea are minor $(\sim 5 \%)$ compared to the marine supply, modern sediment deposits in this region sequester on average $6.0 \mathrm{~g} / \mathrm{m}^{2}$ year organic carbon, or $5.8 \%$ of the annual integrated pelagic primary production. This burial fraction exceeds, by a factor of 3 , the burial fraction derived for the Holocene.
\end{abstract}

KEY WORDS: aerosols, mercury, organic matter, organic carbon, Arctic. 


\section{INTRODUCTION}

Civilization leads to emissions of anthropogenic substances to the environment. The most affected regions are those immediately boarding highly populated or/and industrialized areas. Therefore it came as a surprise, some decades ago, that both the Arctic and the Antarctic are, in several respects, strongly affected by chemical and physical contamination.

Both by extending commercial activities in the Arctic, and due to the 'grasshopper effect' long range transport of conyaminants in subsequent deposition reemission cycles are transported to the areas that even some years ago were considered pristine.

This concerns well known contaminants, e.g. heavy metals and persistent organic pollutants and radinuclides (Zaborska et al. 2010), as well as components of the environment that have always been looked at as 'natural'. One such component is atmospheric aerosol. The Arctic is not a pristine region, as it is often thought to be, also since the atmospheric turbidity conditions are frequently subject to strong changes due to haze and dust transport episodes, which can cause considerable perturbations on the radiation balance of the atmosphere beyond regional scale. This, directly or indirectly contributes to the increased mercury deposition and carbon cycling.

Mercury, both used in production and contained in energy carriers and waste, is in the major portion emitted to the atmosphere, which led to an increased atmospheric mercury concentration in past decades (Slemr and Langer 1992). Gaseous mercury is characterized by long residence times in the troposphere, which allows it to be transported to the Arctic (Steffen and Douglas et al. 2008). Elevated gaseous mercury levels in the Canadian Arctic were reported since the early nineties, but in the late nineties, by examination of long time series, a sudden drop of gaseous mercury concentration was observed in spring, which latter appeared to be an annual phenomenon (Schroeder and Anlauf et al. 1998). It was named later an Atmospheric Mercury Depletion Event (AMDE). It is now well established knowledge that AMDEs occur through polar regions, a phenomenon which was described in over 200 papers in 5 years since the first report. Depletion events are a consequence of mechanisms leading to a very fast removal of mercury from the atmosphere from the $1 \mathrm{~km}$ thick air/sea and air/land boundary layer. It is therefore estimated that AMDEs are responsible for the deposition of roughly 300 tonnes of mercury each year (Ariya and Dastoor 2004), which leads to its elevated levels in the arctic wildlife, especially marine mammals, and in some locations it has been found in dangerous concentrations in cord blood of mothers (Wagemann and Trebacz 1998, Arnold and Ayotte 2003).

Another important area related to climate change is the burial of carbon in the marine sediments. The increased fluxes of organic matter to sediments indicate an increased sequestration of carbon, a phenomenon favourable for carbon concentration in the atmosphere, still a phenomenon enhanced by increased nutrients concentrations. Loadings of nutrients are brought from land with the river runoff and from the atmospheric wet and dry depositions. 
In this paper we present a short summary of the recent findings on the extent to which various parts of the European Arctic are affected by the global change. The results presented here originate from investigations carried out in the Institute of Oceanology PAN in Sopot over the past decade.

\section{MATERIALS AND METHODS}

Map of the study area is presented in Figure 1.

Aerosol related investigation was carried out in the Greenland Sea, factors influencing mercury distribution were evaluated basing on research centered in the fjords of Spitsbergen, while studies on organic carbon deposition to sediments were carried out in the Barents Sea.

Figure 1. Map showing the study area

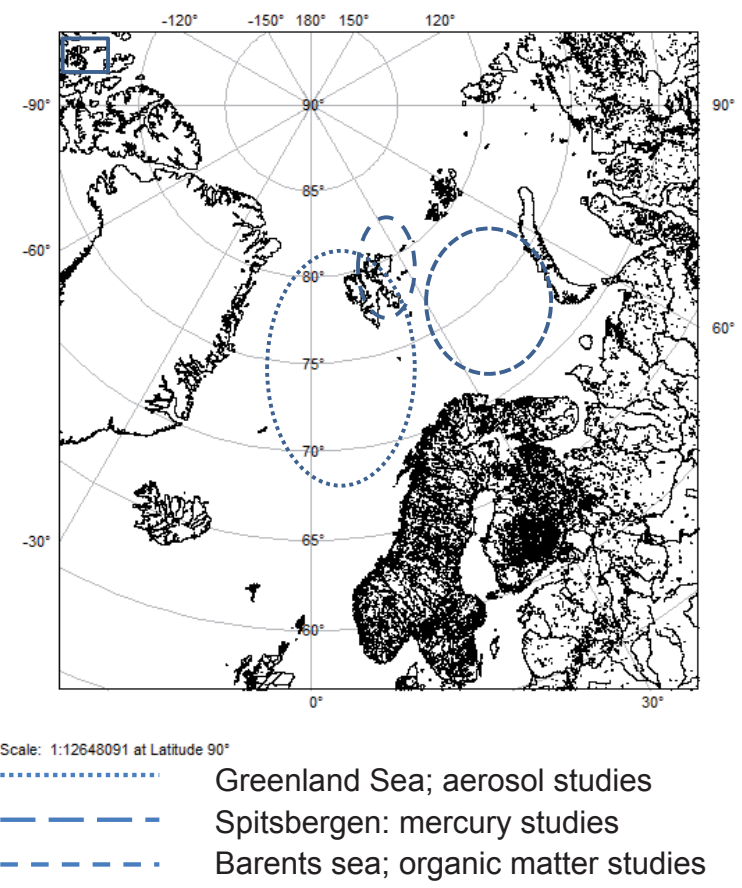

\section{Aerosols}

The aerosol studies discussed in this work were carried out during IOPAS ARctic EXperiment (AREX) campaigns from the board of s/y Oceania between 2000 and 2010. During each campaign the vessel cruised for six weeks in the European Arctic between $0^{\circ}$ and $14^{\circ} \mathrm{E}$ and $69^{\circ}$ and $81^{\circ} \mathrm{N}$. This research was partly made within the framework of the NASA Maritime Aerosol Network (MAN) and during the ASTAR 2007 campaign. Aerosol studies were conducted using an ensemble of instruments, including lidars (aerosol vertical concentrations), particle counters (size distributions) and sun photometers. The laser particle counter was placed on a 
mast of the vessel and moved vertically, which facilitated the determination of the vertical structure of aerosol concentrations and their sizedistribution at altitudes of up to $20 \mathrm{~m}$ amsl. Simultaneously, lidars provided both horizontal and vertical profiles of aerosol concentrations at altitudes of up to $3500 \mathrm{~m}$ AMSL and sun photometers provided the aerosol optical depth (AOD) data. The full meteorological coverage was provided by the ship meteo and the HYSPLIT (Zielinski et al. 2005).

\section{Mercury}

Surficial sediments were collected in the period 2005-2008 by means of a Reineck type box corer or a Niemisto type gravity corer. The top centimeter of sediment was sampled by cutting it away with a stainless steel blade, whereas the fluffy layer of suspended matter covering the sediments was collected with a syringe.

Water samples for mercury analysis were obtained by siphoning near-bottom water onboard with an all-Teflon pump and passing it through ignited glass filters (pore size $0.45 \mu \mathrm{m}$ ). Samples were stored in borosilicate bottles with Teflon caps, pre-cleaned by storing $4 \mathrm{M}$ nitric acid in them for a week, then rinsed with $1 \% \mathrm{HNO} 3$ in MilliQ water. The details of the analytical procedure are described elsewhere (Bełdowski, Pempkowiak 2009). For a total mercury analysis the samples were digested with acids (HNO3:HClO4:HF) and the resulting solutions were diluted with MilliQ water prior to analysis (for details - see Pempkowiak et al. 1998).

\section{Sedimentation rates}

Sediment accumulation rates (SAR in $\mathrm{cm} /$ year) were determined from the profiles of excess ${ }^{210} \mathrm{~Pb}\left({ }^{210} \mathrm{~Pb}_{\text {supp }}\right.$ was subtracted from total $\left.{ }^{210} \mathrm{~Pb}\right)$ versus porosity-corrected depth in sediments. The details of the activity concentration measurements, and the mathematical model applied for SAR calculations are presented by Zaborska et al. (2008), and Szczepańska et al. (2009).

\section{RESULTS}

\section{Aerosols}

In this work we report the results of the AOD studies with sun photometers. It is a measure of light extinction in an atmospheric column and depends on aerosol concentration, particle size distribution, optical properties and the source and history of air masses (Smirnov et al. 2002). The knowledge of real variations of this parameter facilitates the solution of problems with solar radiation transmission through the atmosphere, as well as those concerning climatology and remote sensing of the seas and oceans. Typical AOD $(500 \mathrm{~nm})$ values are in the range from 0.01 to 0.1 . Time patterns of the daily mean values not only give a measure of the changes in the columnar aerosol extinction features, but also offer evidence for the marked changes in AOD due to the presence of the Arctic haze ( $\mathrm{Ah} ; \mathrm{AOD}=0.2$ ) 
and important transport episodes (Asian dust; $\mathrm{AOD}=0.3$, and boreal smokes; $\mathrm{AOD}=0.6$ - in summer 2004) (Tomasi et al. 2007). The Arctic haze conditions (AOD values exceeding 0.1 at $500 \mathrm{~nm}$ ) mostly occur in spring.

It was observed by the authors during the studies that spring 2006 was the worst in 15 years in terms of air pollution (Fig. 2).

Figure 2. AOD values measured at different wavelengths in Ny Alesund in March 2006

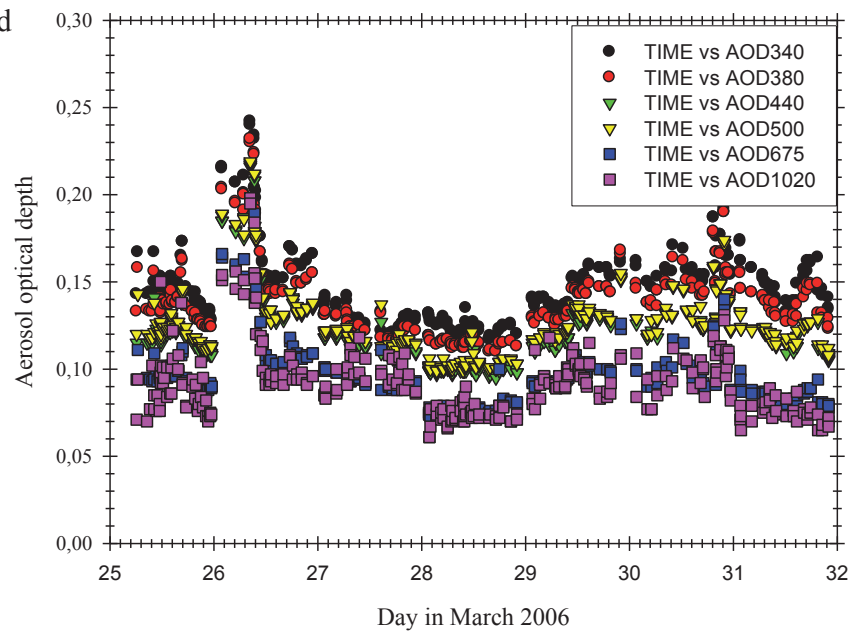

It is obvious that during the entire measurement period the AOD values exceeded 0.1 at $500 \mathrm{~nm}$ and there was one particularly strong case of the Arctic haze on 26 March, when the AOD at $500 \mathrm{~nm}$ reached values higher than 0.22. During the 2007 ASTAR campaign (March-May) the Arctic haze conditions were observed during only one day in the southern Spitsbergen area. Such small representation of the Arctic haze conditions can be related to a shift of ice covered areas higher up north (Fig. 3).

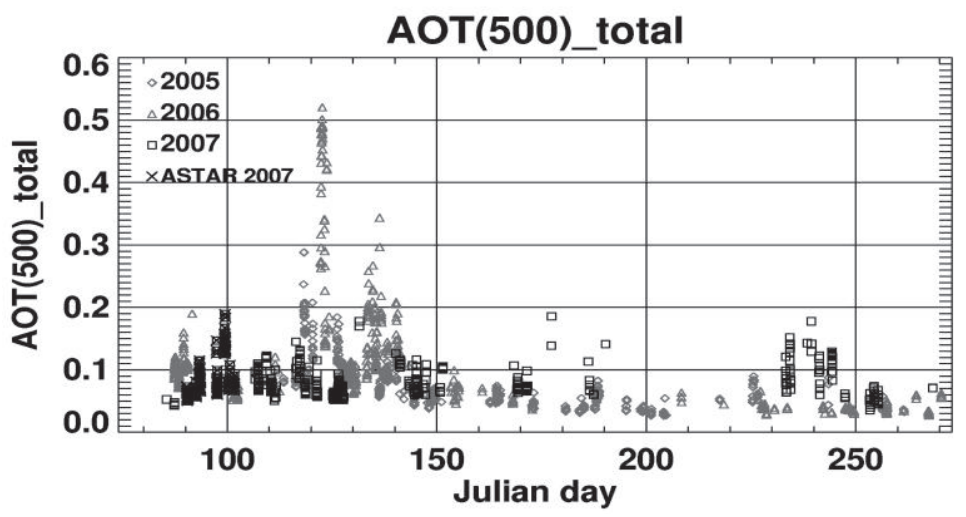

Figure 3. AOD values at $500 \mathrm{~nm}$ versus time measured in Hornsund 
The days with higher AOD values in Hornsund were attributed to the influence of air masses advected directly from the north. In these cases air mass trajectories did not run over the sea. This has been confirmed also using the cluster analyses (Rozwadowska et al. 2010).

The data indicate that, over the years, the Arctic haze is weakened due to a decrease of ice coverage in the Arctic. This would be a major consequence of the climate warming. To confirm this thesis all AOD data collected in Koldeway in the period 1995-2008 have been analyzed and compared with the ice coverage of the sea in the Spitsbergen region.

A significant correlation has been obtained between the sea surface area free of ice in March and the average AOD value in April $(\mathrm{R}=0.7)$. There is also a correlation between the ice-free sea surface area and the minimum monthly AOD in April recorded in Ny-Alesund. There is no correlation between the maximum AOD values and the ice sea coverage. The maximum AOD values are connected with the advection of air masses from remote areas.

However, higher AODs are observed not only in spring, but in other seasons as well. Table 1 presents the daily averaged AOD at $500 \mathrm{~nm}$ obtained during the s/y Oceania cruise in the area of Spitsbergen in 2009

(http://aeronet.gsfc.nasa.gov/new_web/maritime_aerosol_network.html).

Table 1. Daily averaged AOD $(500 \mathrm{~nm})$ at different locations in the Spitsbergen area in 2009

\begin{tabular}{|c|c|}
\hline Day in July 2009 & AOD at 500 nm \\
\hline 2.07 & 0.075 \\
\hline 3.07 & 0.143 \\
\hline 4.07 & 0.079 \\
\hline 5.07 & 0.150 \\
\hline 8.07 & 0.112 \\
\hline 9.07 & 0.109 \\
\hline 10.07 & 0.145 \\
\hline 11.07 & 0.141 \\
\hline 12.07 & 0.122 \\
\hline 13.07 & 0.146 \\
\hline
\end{tabular}

The AOD values were higher than 0.1 with exceptions to 2 and 4 July, 2009. On other days the AOD values indicated atmospheric pollution conditions in the area of the western Spitsbergen. Nevertheless, mean summer AOD at $500 \mathrm{~nm}$ values usually do not exceed 0.1 . One explanation would be that this phenomenon does not necessarily mean the Arctic haze. Since these values were obtained in summer over the sea, then humidity may be an important factor, but further work on the subject is required. 


\section{Mercury}

Cores from the Barents Sea show subsurface maximum of mercury close to the mixing depth (Fig. 4) - behavior similar to that found in the Baltic Sea, which is typical for sediments receiving mercury pollution. Such pattern has been attributed, elsewhere, to a constant mercury input and a partial return of mercury from the uppermost sediments to the water column (Bełdowski and Pempkowiak 2009).

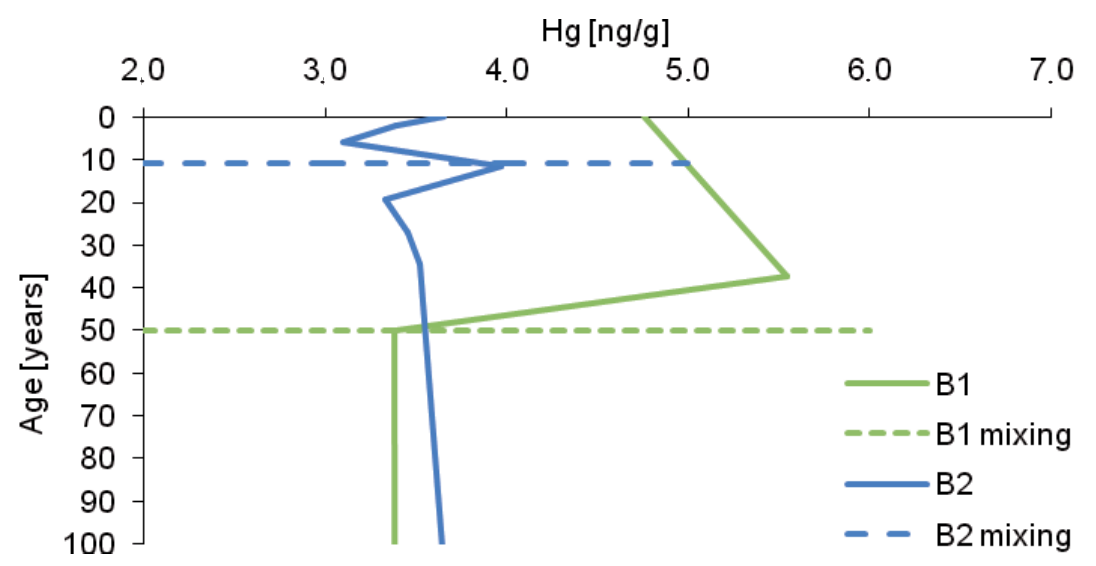

Figure 4. Mercury concentration in Barents Sea cores

However, taking into account the age of sediments, one might claim that core $4 \mathrm{~A}$, located at the southern Barents Sea exhibits an undisturbed sedimentary record, with peak mercury concentrations deposited $\sim 30$ years ago and a constant decrease till present. This is contradicted by the location of the mixing depth - confirmed by ${ }^{210} \mathrm{~Pb}$ measurements. It seems likely that we are observing an AMDE mercury pulse in both Barents Sea cores, still on the surface in the northern core, and a bit deeper in the southern core, resulting from the earlier AMDE occurring at lower latitudes.

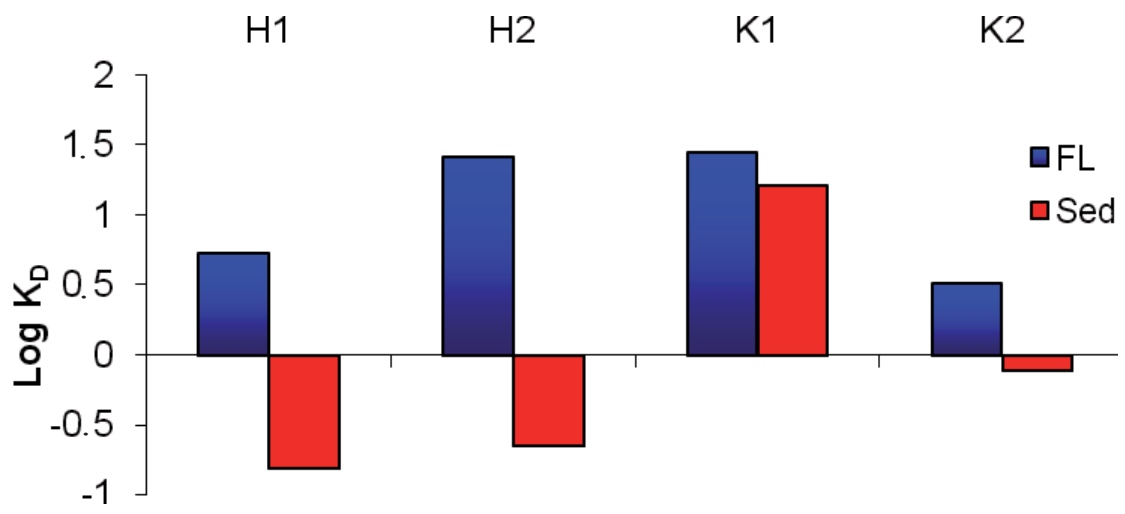

Figure 5. Hg dissolved/solid partitioning in fluffy layer of suspended matter (FL) and uppermost sediments (Sed) in Hornsund (H1, H2) and Kongsfjorden (K1, K2) 
Cores from Spitsbergen Fjords - Hornsund, from the south and Kongsfjorden, from the north, should display, then, similar behavior. We concentrated on the $\mathrm{Hg}$ dissolved/solid partitioning,, both in the unconsolidated, fluffy layer of suspended matter covering the sediments, and the uppermost sediment layer (Fig. 5). It seems that in Kongsfjorden, dissolved mercury prevails in both media, while in Hornsund we can see different mercury behaviours in unconsolidated and consolidated sediments. This might indicate that AMDE pulse in northern Spitsbergen is still present on the surface of sediments, while in the southern fjord, it has already been transferred into sediments and/or water column.

These results indicate that in the northern Barents Sea and on Spitsbergen the influence of AMDE can prolong well into summer (July/August), and while sediment/water interface does not interact with zooplankton, it is a habitat of numerous benthic animals, which can provide a pathway to the food chain for mercury contained in sediments. Hence, AMDE influence on Arctic ecosystem might be not limited to the relatively short polar spring, and a larger part of mercury load to the Arctic should be considered a threat than previously suspected.

\section{Organic matter}

The linear sediment accumulation rates for 14 stations in the Barents Sea ranged from 0.2 to $1.3 \mathrm{mmyr}^{-1}$ (Zaborska et al. 2008). Mass sediment accumulation rates varied from 320 to $650 \mathrm{~g} \mathrm{~m}^{-2} \mathrm{yr}^{-1}$ (Zaborska et al. 2008). In general, lower sediment accumulation rates were measured in regions of shallower water depths, where currents remove fine-grained material. In deeper regions and underwater canyons sediment accumulation rates were higher. Surface sediments were mixed at almost all the stations to a depth of $1-2.5 \mathrm{~cm}$. Short-term ( $<3$ months) mixing rate coefficients determined from ${ }^{234} \mathrm{Th}$ mixing profiles ranged from 1 to $12 \mathrm{~cm}^{2} \mathrm{yr}^{-1}$ (Carroll et al. 2008). Long-term ( $<100$ years) mixing rate coefficients determined from ${ }^{210} \mathrm{~Pb}$ profiles ranged from $0.07-0.4 \mathrm{~cm}^{2} \mathrm{yr}^{-1}$ (Carroll et al. 2008). The highest mixing was measured at the stations in underwater canyons, where turbidity currents may cause sediment resuspension.

Organic carbon concentration in the Barents Sea sediment varied from $0.9 \%$ to $2.6 \%$ (Zaborska et al. 2008). The $\mathrm{C} / \mathrm{N}$ ratio of sediments (ranging from 5.8-14.2) indicated a predominance of material of marine origin (Zaborska et al. 2008). The highest organic carbon content in sediments was measured at the stations with the highest primary production. Sedimentary organic carbon content varies little with sediment depth, implying that there is little variation in carbon burial rates over decadal to 100-year-time-scales. Organic matter accumulated at the bottom undergoes mineralization or is buried and preserved in the sediments. The organic carbon burial rates in the northwest Barents Sea ranged from 3.0-8.7 $\mathrm{g} \mathrm{C} \mathrm{m}^{-2} \mathrm{yr}^{-1}$ (Fig. 6).

Since terrigenous supplies of organic carbon to the Barents Sea are minor $(\sim 5 \%)$ compared to the marine supply, modern sediment deposits in this region 
Figure 6. Organic carbon burial rates in the Barents Sea $\left(\mathrm{gC} / \mathrm{m}^{2}\right.$ year $)$

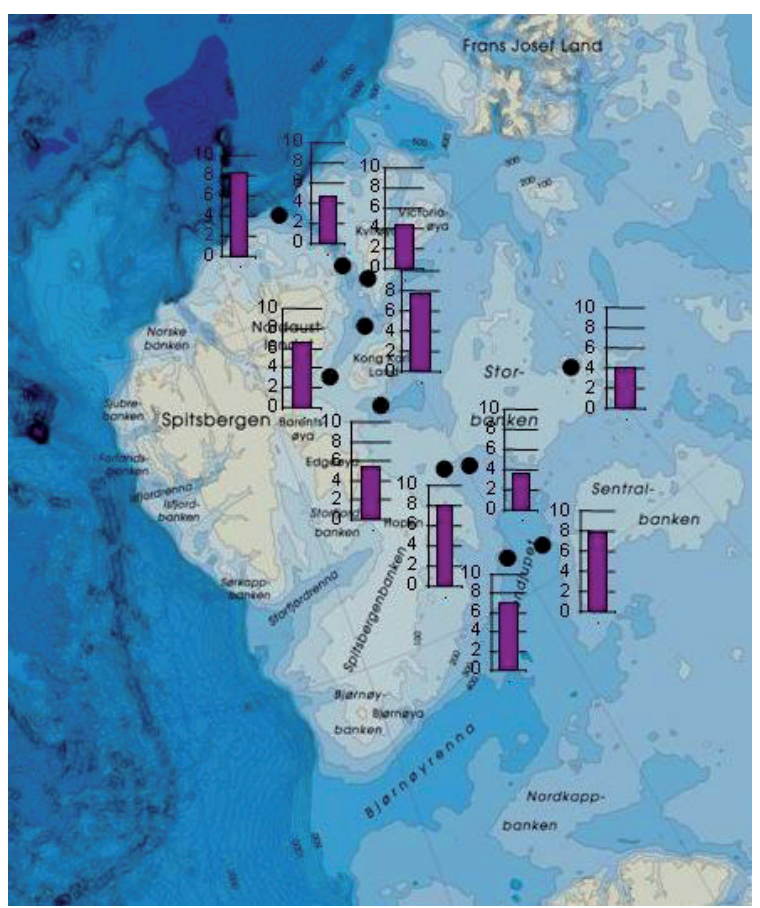

sequester roughly $3.1-8.9 \%$, mean $5.8 \%$, of the annual integrated pelagic primary production $\left(93 \mathrm{~g} \mathrm{C} \mathrm{m}^{-2}\right)$. This burial fraction is higher by a factor of 3 than the burial fraction derived for the Holocene (Carroll et al. 2008).

\section{DISCUSSION}

Polar regions are predicted to incur some of the most pronounced effects of global climate change. Scenarios of future climatic development predict changes in the air and sea water temperature, as well as the extent of ice cover and ice thickness. This, without doubt, will result in significant alterations of the marine ecosystem and the global carbon cycle. This study indicates that the effects will concern both physical and chemical properties of the environment over the entire area.

The results show that local emissions are not always the most important factors which influence the composition of aerosol in the atmosphere of the Arctic. The direct radiative impact of polar aerosols on the surface and at the TOA need to be studied more closely through both theoretical studies on the aerosol radiative properties and measurements of the surface reflectance characteristics. The verification of the theoretical results requires the continuous monitoring of aerosol optical properties in conjunction with surface radiation budget measurements. In particular, aerosol 
properties obtained from in-situ measurements should be compared with those provided by sun-radiometers along the sun path and photometer techniques on the surface, and both techniques could be combined to integrate the radiative effects of aerosols along the entire atmospheric column.

Studies on aerosol physical properties need to be combined with an analysis of the chemical composition of aerosols collected in the study area at various times. This would answer the question to what extent aerosols contribute to the developing distribution of certain chemicals (e.g. mercury), and carry loads of organic matter to the Arctic. The former is important for understanding the reasons for the increased mercury concentration in the Arctic environment, including marine sediments. The latter would explain the recent increase of organic matter deposited to marine sediments in the study area.

\section{ACKNOWLEDGMENTS}

The results presented in this publication were obtained within the framework of the following scientific programmes: AREX Project, the Polish National Grant POLAR-AOD, the NASA Maritime Aerosol Network, On Thin Ice, and Cabanerra. The organizational and financial support is highly appreciated. The study is a part of the Institute of Oceanology PAN, Sopot statutory activities no I.3, and II. 2.

\section{REFERENCES}

Ariya P. A., Dastoor A. P., 2004, The Arctic: a sink for mercury, Tellus Series B-Chemical and Physical Meteorology, 56(5), 397-403.

Arnold D., AyotteP., 2003, Canadian Arctic Contaminants Assessment Report II, Ottawa, Human Health, Indian Affairs and Northern Development, 127.

Bełdowski J., Pempkowiak J., 2009, Mercury concentration and speciation changes in the course of early diagenesis in marine coastal sediments (Southern Baltic Sea), Journal of Marine and Freshwater Research, 60, 745-757.

Bełdowski J., Miotk M., Pempkowiak J., 2009, Mercury fluxes through the sediment water interface and bioavailability of mercury in southern Baltic Sea sediments, Oceanologia, 51 (2), 263-285.

Carroll J., Zaborska A., Papucci C., Schirone A., Carroll M.L., Pempkowiak J., 2008, Accumulation of organic carbon in western Barents Sea sediments, Deep-Sea Research II 55 (20-21), 2361-2371.

Law K.S., Stohl A., 2007, Arctic air pollution: Origins and impacts, Science, 315 (5818), $1537-1540$.

Pempkowiak J., Cossa D., Sikora A., Sanjuan J., 1998, Mercury in water and sediments of the southern Baltic Sea, Science of the Total Environment, 213 (1-3), 185-192.

Rozwadowska A., Zieliński T., Petelski T., Sobolewski P., 2010, Cluster analysis of the impact of air back trajectories on aerosol optical properties at Hornsund, Spitsbergen, Atmospheric Chemistry and Physics, 10, (3), 877-893. 
Smirnov A., Holben B. N., Eck T. F., Slutsker I., Chatenet B., Pinker R. T., 2002, Diurnal variability of aerosol optical depth observed at AERONET (Aerosol Robotic Network) sites, Geophysical Research Letters , 29 (23), 2115, doi:10.1029/2002GL016305.

Schroeder W. H., Anlauf K. G., Barrie L. A., Lu J. Y., Steffen A., Schneeberger D. R., Berg T., 1998, Arctic springtime depletion of mercury, Nature, 394(6691), 331-332.

Slemr F. and. Langer E., 1992, Increase in Global Atmospheric Concentrations of Mercury Inferred from Measurements over the Atlantic-Ocean, Nature, 355(6359), 434-437.

Steffen A., Douglas T., Amyot M., Ariya P., Aspmo K., Berg T., Bottenheim J., Brooks S., Cobbett F., Dastoor A., Dommerque A., Ebinghaus R., Ferari C., Gardfeldt K., Goodsite M. E., Leon D., Paulain A. J., Scherz C., Sokov H., Sommar J., Temme C., 2008, A synthesis of atmospheric mercury depletion event chemistry in the atmosphere and snow, Atmospheric Chemistry and Physics, 8(6), 1445-1482.

Szczepańska A., Zaborska A., Pempkowiak J., 2009, Sediment accumulation rates in the Gotland deep, Baltic proper obtained by ${ }^{210} \mathrm{~Pb}$ and ${ }^{137} \mathrm{Cs}$ methods, Rocznik Ochrony Środowiska, 11, 77-85.

Tomasi C., Vitale V., Lupi A., Carmine C. D., Campanelli M., Herber A., Treffeisen R., Stone R. S., Andrews E., Sharma S., Radionov V., von Hoyningen-Huene W., Stebel K., Hansen G., Myhre C. L., Wehrli C., Aaltonen V., Lihavainen H., Virkkula A., Hillamo R., Ström J., Toledano C., Cachorro V., Ortiz P., de Frutos A., Blindheim S., Frioud M., Gausa M., Zielinski T., Petelski T., Shiobara M., 2007, Aerosols in Polar regions: A historical review on the basis of optical depth and in-situ observations, Journal Geophysical Research, 112, D16205, doi:10.1029/2007JD008432.

Wagemann R., Trebacz E., 1998, Methylmercury and total mercury in tissues of arctic marine mammals, Science of the Total Environment, 218(1), 19-31.

Zaborska A., Carroll J., Papucci C., Torricelli L., Carroll M.L., Walkusz-Miotk J., Pempkowiak J., 2008, Recent sediment accumulation rates for the Western margin of the Barents Sea, Deep-Sea Research II, 55 (20-21), 2352-2360.

Zaborska A., Mietelski J.W., Carroll J., Papucci C., Pempkowiak J., 2010, Sources and distributions of ${ }^{137} \mathrm{Cs},{ }^{238} \mathrm{Pu}$ and ${ }^{239,240} \mathrm{Pu}$ in the Barents Sea, Journal of Environmental Radioactivity, 101 (4), 323-331.

Zieliński, T., Petelski, T., Rozwadowska, A., 2005, Aerosol optical properties in the Arctic region, Proceedings of the Annual American Association for Aerosol Research Annual Conference, 1PH16, 59. 